\title{
LETTER
}

\section{Abnormal saline: the unphysiological bag of brine}

\author{
Mourad H Senussi \\ See related research by Duburcq et al., http://ccforum.com/content/18/4/467
}

Duburcq and colleagues, in their article published in Critical Care, showed improved oxygenation, hemodynamic parameters, and microvascular reactivity in an experimental porcine endotoxic shock model with use of hypertonic sodium lactate $11.2 \%$ [1]. We applaud the authors for embarking on the arduous quest for the ideal resuscitative fluid, which has historically been fraught with shortcomings.

The control group in this experimental model was subjected to an infusion of $0.9 \%$ normal saline. Normal saline has become almost ubiquitous in patient care. More evidence is emerging that this so-called lifeblood, as unphysiological as it is, may be causing undue harm to our patients. A $0.9 \%$ normal saline infusion has been demonstrated to cause decreased renal blood flow velocity and renal cortical tissue perfusion in healthy volunteers [2]. Abnormal saline was also associated with increased incidence of acute kidney injury and need for renal replacement therapy in a cohort of critically ill patients [3] and had a higher in-hospital mortality rate than more balanced salt solutions [4]. The significant chloride content of normal saline has been implicated in its adverse effect on acid-base status. It has become more evident that the use of balanced salt solutions may be associated with reduced mortality in the septic population $[4,5]$.

Given the mounting evidence against the use of normal saline, I believe it would be better served if, firstly, the normal saline arm is replaced with one with a balanced salt solution. Secondly, I suggest the experimental model should include a true control arm that did not receive any resuscitative fluids.

\section{Competing interests}

The author declares that he has no competing interests.

Published online: 28 November 2014

\section{References}

1. Duburcq T, Favory R, Mathieu D, Hubert T, Mangalaboyi J, Gmyr V, Quintane L, Maboudou P, Pattou F, Jourdain M: Hypertonic sodium lactate improves fluid balance and hemodynamics in porcine endotoxic shock. Crit Care 2014, 18:467.

2. Chowdhury AH, Cox EF, Francis ST, Lobo DN: A randomized, controlled, double-blind crossover study on the effects of $2-L$ infusions of $0.9 \%$ saline and plasma-lyte ${ }^{\circledast} 148$ on renal blood flow velocity and renal cortical tissue perfusion in healthy volunteers. Ann Surg 2012, 256:18-24.

3. Yunos NM, Bellomo R, Hegarty C, Story D, Ho L, Bailey M: Association between a chloride-liberal vs chloride-restrictive intravenous fluid administration strategy and kidney injury in critically ill adults. JAMA 2012, 308:1566-1572.

4. Raghunathan K, Shaw A, Nathanson B, Stürmer T, Brookhart A, Stefan MS, Setoguchi S, Beadles C, Lindenauer PK: Association between the choice of IV crystalloid and in-hospital mortality among critically ill adults with sepsis. Crit Care Med 2014, 42:1585-1591.

5. Rochwerg B, Alhazzani W, Sindi A, Heels-Ansdell D, Thabane L, Fox-Robichaud A, Mbuagbaw L, Szczeklik W, Alshamsi F, Altayyar S, Ip WC, Li G, Wang M, Wludarczyk A, Zhou Q, Guyatt GH, Cook DJ, Jaeschke R, Annane D, Fluids in Sepsis and Septic Shock Group: Fluid resuscitation in sepsis: a systematic review and network meta-analysis. Ann Intern Med 2014, 161:347-355.

doi:10.1186/s13054-014-0673-z

Cite this article as: Senussi: Abnormal saline: the unphysiological bag of brine. Critical Care 2014 18:673. 